See discussions, stats, and author profiles for this publication at: https://www.researchgate.net/publication/235361621

\title{
The Relationship Between Culture and Behavioral Intentions Toward Services
}

Article in J ournal of Service Research · August 2001

CITATIONS

129

3authors:

(2) Ben SLiu

Quinnipiac University

72 PUBLICATIONS 1,578CTTATIONS

SEE PROFILE

D. Sudharshan

University of Kentucky

72 PUBLICATIONS 2,700 CITATIONS

SEE PROFILE

Some of the authors of this publication are also working on these related projects:

Project Case Studies View project

Project J ump Theory View project
READS

121

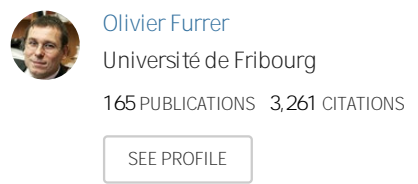




\title{
The Relationships Between Culture and Behavioral Intentions Toward Services
}

\author{
Ben Shaw-Ching Liu
}

Butler University

\section{Olivier Furrer}

University of Birmingham, United Kingdom

\section{Sudharshan}

University of Illinois at Urbana-Champaign

Some recent studies have shown that culture influences how consumers perceive service quality. Others have shown the relationship between perceived service quality and behavioral intentions. In this article, the authors study how culture influences behavioral intentions toward services on the basis of services marketing and cross-cultural psychology literature. They tested and found that customers from cultures with lower individualism or higher uncertainty avoidance tend to have a higher intention to praise if they received superior service. On the other hand, the same groups tend not to switch, give negative word of mouth, or complain even if they received poor service quality. Customers from cultures with higher individualism or lower uncertainty avoidance tend to switch, engage in negative word of mouth, or complain if they received poor service quality. But they do not tend to praise when they received superior service. Managerial implications, contribution, and future research directions are also discussed.

In this article, ${ }^{1}$ we seek to add to our understanding of the effect of culture on customer behavior toward services by studying the relationship between culture and behavioral intentions in a service quality context.

Journal of Service Research, Volume 4, No. 2, November 2001 118-129 (C) 2001 Sage Publications
Various studies, such as Parasuraman, Zeithaml, and Berry (1988, 1994); Boulding et al. (1993); Zeithaml, Berry, and Parasuraman (1996); and Liu, Sudharshan, and Hamer (2000), have found perceived service quality to have an effect on several types of behavioral intentions. For example, Zeithaml, Berry, and Parasuraman (1996) found that perceived service quality has (a) positive effects on loyalty to a company and willingness to pay more and (b) negative effects on propensity to switch and to engage in an external response to a problem. But they did not find any significant effects of service quality on internal response to a problem. Other recent studies have found that customers from different cultures formed different perceptions of the service quality of the same stimuli either because of differences in expectations or because they attached different weights to different service quality criteria. For example, Donthu and Yoo (1998) found that customers' cultural orientation affects their service quality expectations. Mattila (1999) found that customers with Western cultural backgrounds are more likely to rely on tangible cues from a physical environment to evaluate service quality than are their Asian counterparts. More re-

1. At the outset, we wish to point out that the data used for the present article were collected as a part of a larger project, of which the first published report was that by Furrer, Liu, and Sudharshan (2000). 
cently, Furrer, Liu, and Sudharshan (2000) found that customers from different cultures assigned different importance weights to the five SERVQUAL dimensions for measuring perceived service quality. In summary, the extant literature documents investigations of the effects of culture on perceived service quality and of perceived service quality on behavioral intentions. We investigate the next step in this line of inquiry, by studying the relationship between culture and behavioral intentions in a service quality context. Specifically, we show that cultural factors influence customers' behavioral intentions by influencing the perception of service quality. Our article provides both a theoretical and an empirical contribution to the services marketing literature.

This article is organized as follows: First, we present the literature discussing the pairwise relationships between culture and perceived service quality, perceived service quality and behavioral intention, and between culture and behavior. Second, we develop hypotheses about the relationships between cultural factors and behavioral intentions in service situations. Third, we describe the methodology that we used to test our hypotheses and then present the results of our empirical study. Finally, we discuss some managerial implications of our study and future research directions.

\section{LITERATURE REVIEW}

\section{The Relationships Between Culture, Perceived Service Quality, and Behavioral Intentions}

Some recent studies have already started the investigation on how cultural dimensions influence satisfaction and perceived service quality (e.g., Bianchi 2001; Donthu and Yoo 1998; Furrer, Liu, and Sudharshan 2000; Malhotra, Ugaldo, Agarwal, and Baalbaki 1994; Mattila 1999; Reisinger and Turner 1999; Strauss and Mang 1999; Sultan and Simpson 2000; Winsted 1997, 1999). A review of much of this literature can be found in Furrer, Liu, and Sudharshan (2000). Overall, these studies found that customers from different cultures have different perceptions of service quality. Table 1 summarizes this literature and its principal findings.

However, none of these studies have explicitly addressed the issue of the relationship between culture and behavioral intentions. Behavioral intentions have been studied as intervening variables between service quality and financial performance (Zeithaml, Berry, and Parasuraman 1996). Several studies (e.g., Brown 1997; Tax, Brown, and Chandrashekaren 1996) indicate that upset customers may tell, on average, 10 to 20 people about their negative experiences. With the increasing use of the Internet, communication among customers will soar. This reality of the extent and speed of word-of-mouth dissemination and the expectation of "spreading on net" has led many service practitioners to place renewed focus on customer complaint behavior and customer complaint management. The economic impact of customer retention that is most often cited is the calculation carried out for 14 industries by Reichheld (1996; Reichheld and Sasser 1990; Reichheld and Schefter 2000), that the net present value increase in profit that results from a $5 \%$ increase in customer retention varies between $25 \%$ and $95 \%$.

Most of the early studies linking either service quality or customer satisfaction to behavioral intentions used a unidimensional measure of behavioral intentions (e.g., Anderson and Sullivan 1993; Cronin and Taylor 1992; Woodside, Frey, and Daly 1989). These studies found a significant positive relationship between overall customer satisfaction and loyalty or repurchase intention. More recent studies have investigated the effect of customer satisfaction and perceived service quality on various kinds of behavioral intentions such as loyalty, positive word of mouth (Boulding et al. 1993), intentions toward repeat patronage, and intentions toward communication to others (Liu, Sudharshan, and Hamer 2000). Moreover, in their study of the links between service quality and behavioral intentions, Parasuraman and his associates (e.g., Parasuraman, Zeithaml, and Berry 1994; Zeithaml, Berry, and Parasuraman 1996) identified five dimensions of behavioral intentions: loyalty to the company, propensity to switch, willingness to pay more, external response to problem, and internal response to problem. Studying the relative influence of service quality on the five behavioralintention dimensions, they found positive effects with loyalty to company and willingness to pay more, negative effects with propensity to switch and external response to problem, and nonsignificant effects with internal response to problem (Parasuraman, Zeithaml, and Berry 1994; Zeithaml, Berry, and Parasuraman 1996). Bloemer, de Ruyter, and Wetzels (1999), using the same items as Zeithaml, Berry, and Parasuraman (1996), found different dimensions for behavioral intentions: repurchase intentions, word-of-mouth communication, price sensitivity, and complaining behavior. They also found that relationships between service quality and behavioral intentions had notable differences across industries.

\section{The Relationship Between Culture and Behavior}

A majority of the studies of the similarities and differences in individual psychological functioning in various cultural and ethnic groups assume explicitly that culture is 
TABLE 1

SUMMARY OF THE LITERATURE EXAMINING THE RELATIONSHIPS

BETWEEN CULTURE AND SERVICE QUALITY/CUSTOMER SATISFACTION

\begin{tabular}{|c|c|c|c|c|}
\hline Study & $\begin{array}{l}\text { Service Quality } \\
\text { Dimensions/Customer } \\
\quad \text { Satisfaction }\end{array}$ & $\begin{array}{l}\text { Culture/Cultural } \\
\text { Dimensions }\end{array}$ & $\begin{array}{l}\text { Industry } \\
\text { Context }\end{array}$ & Findings \\
\hline $\begin{array}{l}\text { Malhotra } \\
\text { et al. (1994) }\end{array}$ & $\begin{array}{l}\text { Ten dimensions based } \\
\text { on SERVQUAL }\end{array}$ & $\begin{array}{l}\text { Developed and developing countries } \\
\text { evaluated on Individualism, } \\
\text { collectivism, power distance, } \\
\text { time value, and communication }\end{array}$ & Conceptual & $\begin{array}{l}\text { Propose that developing nations are high in power distance and collectivism, and place greater } \\
\text { emphasis on human touch and personal contact than on reliability to assess the quality of } \\
\text { the service. }\end{array}$ \\
\hline Winsted (1997) & $\begin{array}{l}\text { Authenticity, caring, } \\
\text { control, courtesy, } \\
\text { formality, friendliness, } \\
\text { personalization, } \\
\text { promptness }\end{array}$ & Japan and the United States & Restaurant & $\begin{array}{l}\text { Significant differences between the service quality dimensions in Japan and in the United } \\
\text { States. }\end{array}$ \\
\hline $\begin{array}{l}\text { Donthu and } \\
\text { Yoo (1998) }\end{array}$ & SERVQUAL & $\begin{array}{l}\text { Individual level based on Hofstede's } \\
\text { dimensions (Canada, Great Britain, } \\
\text { India, and the United States) }\end{array}$ & Banking & $\begin{array}{l}\text { Negative relationship between power distance and responsiveness and reliability, positive } \\
\text { relationship between individualism and empathy and assurance. }\end{array}$ \\
\hline $\begin{array}{l}\text { Reisinger and } \\
\text { Turner (1999) }\end{array}$ & $\begin{array}{l}\text { Argyle et al.'s (1986) } \\
\text { relationship rules } \\
\text { dimensions }\end{array}$ & Japan and Australia & Tourism & $\begin{array}{l}\text { Five dimensions that differ between Japanese tourists and Australian hosts are courtesy and } \\
\text { responsiveness, competence, interaction, idealism, and communication. }\end{array}$ \\
\hline Mattila (1999) & $\begin{array}{l}\text { Physical environment, } \\
\text { personal service } \\
\text { component, hedonic } \\
\text { dimension }\end{array}$ & Western and Asian customers & Hotel & $\begin{array}{l}\text { Customers with a Western cultural background rely more on tangible cues than Asian ones, } \\
\text { and the hedonic dimension is more important for Westerners than for Asians. }\end{array}$ \\
\hline $\begin{array}{l}\text { Strauss and } \\
\text { Mang (1999) }\end{array}$ & Consumer dissatisfaction & $\begin{array}{l}\text { Japanese, American, and German } \\
\text { passengers }\end{array}$ & Airline & $\begin{array}{l}\text { Cultural differences have a significant effect on service evaluation. Cultural shocks, which } \\
\text { lead to consumer dissatisfaction, occur when service providers do not meet the culturally } \\
\text { determined expectations of foreign customers. }\end{array}$ \\
\hline Winsted (1999) & $\begin{array}{l}\text { Customer satisfaction } \\
\text { with eight service } \\
\text { encounter dimensions } \\
\text { (authenticity, caring, } \\
\text { courtesy, formality, } \\
\text { friendliness, perceived } \\
\text { control, personalization, } \\
\text { promptness) }\end{array}$ & $\begin{array}{l}\text { Status-conscious vs. egalitarian, } \\
\text { collectivistic vs. Individualistic in } \\
\text { Japan and United States }\end{array}$ & $\begin{array}{l}\text { Professional services } \\
\text { and generic services }\end{array}$ & $\begin{array}{l}\text { Formality is found to be more important in status-conscious countries than in egalitarian, and } \\
\text { personalization is more important for professional services, whereas courtesy and } \\
\text { promptness are more important for generic services. Caring and courtesy received the } \\
\text { overall highest ratings as most important to satisfaction with service encounters. }\end{array}$ \\
\hline $\begin{array}{l}\text { Furrer, Liu, and } \\
\text { Sudharshan (2000) }\end{array}$ & $\begin{array}{l}\text { Importance of SERVQUAL } \\
\text { dimensions }\end{array}$ & $\begin{array}{l}\text { Individual level based on Hofstede's } \\
\text { dimensions (USA, China, } \\
\text { Singapore, South Korea, } \\
\text { Switzerland) }\end{array}$ & Banking & $\begin{array}{l}21 \text { of the } 25 \text { possible relationships between SERVQUAL and Hofstede's five cultural } \\
\text { dimensions are significant as hypothesized. }\end{array}$ \\
\hline $\begin{array}{l}\text { Sultan and } \\
\text { Simpson (2000) }\end{array}$ & SERVQUAL & American and European passengers & Airlines & $\begin{array}{l}\text { The relative importance of SERVQUAL dimensions are significantly different for reliability } \\
\text { and tangibility, but not for responsiveness, assurance, or empathy. Differences in terms of } \\
\text { expectations and service quality perceptions are also found significant. }\end{array}$ \\
\hline Bianchi (2001) & $\begin{array}{l}\text { Customer satisfaction with } \\
\text { the service encounter }\end{array}$ & $\begin{array}{l}\text { Individualism, power distance, } \\
\text { uncertainty avoidance, masculinity } \\
\text { at country level (Hofstede 1980) }\end{array}$ & Conceptual & $\begin{array}{l}\text { Propose that relationships between cultural differences and customer satisfaction with the } \\
\text { service encounter are mediated by congruency in expectations and mutual understanding } \\
\text { and moderated by intangibility and proximity. }\end{array}$ \\
\hline
\end{tabular}


an antecedent to human thought and behavior (e.g., Berry et al. 1992; Triandis 1994). For example, Berry et al. (1992) have proposed that the major orientations in crosscultural psychology tend to assume cultural explanations for psychological and behavioral differences among groups of people. A second approach that attempts to describe culture in terms of the constraints that limit, rather than determine, a group's behavioral repertoire also assigns antecedent status to culture (Poortinga 1990). Shweder (1990) stated that "cultural traditions . . . regulate ... the human psyche, resulting . . . in ethnic divergences in mind, self, and emotion" (p. 1). Triandis (1980) proposed that social behavior is a function not only of prior habits but also of self-instructions (intentions) to act in specific ways in particular social situations. Such selfinstructions are determined by sociocultural norms about appropriate behavior, expectations about possible consequences of performing the behavior, and affective reactions. Thus, the utility of the behavior in the social as well as in the personal domain is a fundamental component of the intention to perform it.

On the basis of the marketing literature cited above and the relevant cross-cultural psychology literature, we reason that cultural factors are part of the fundamental factors contributing to the formation of a person's general perceptual lens. Specifically, we reason that cultural factors may influence customer behavioral intentions through perceived service quality, which in turn is influenced by a service quality perceptual lens. A pictorial overview and visual aid showing the connections between the various service quality constructs and cultural dimensions is provided in Figure 1.

The literature briefly reviewed above provides the motivation for, and insights leading to, the set of hypotheses described in the next section.

\section{HYPOTHESES}

To study the relationships between culture and behavioral intentions, we hypothesized relationships between Hofstede's cultural dimensions: power distance, individualism, masculinity, uncertainty avoidance, and long-term orientation and the five more common categories of behavioral intentions. The behavioral intentions toward banking services are loyalty to the company, propensity to switch, positive word of mouth, negative word of mouth, and complaining. Extended discussions of the five cultural dimensions can be found in Hofstede $(1980,1991)$ and Bond et al. (1987), and more recently in the marketing context in the articles by Sødergaard (1994); Nakata and Sivakumar (1996); Donthu and Yoo (1998); Sivakumar and Nakata (1999); and Furrer, Liu, and Sudharshan

\section{FIGURE 1 Relationship Between Culture and Behavioral Intentions}

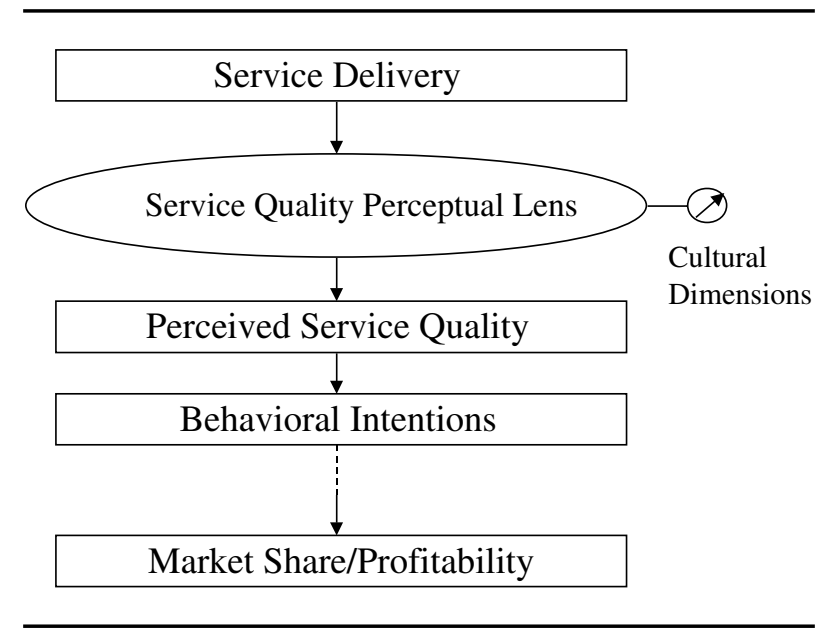

(2000). For a discussion of the five behavioral-intention dimensions, please refer to Zeithaml, Berry, and Parasuraman (1996) and Bloemer, de Ruyter, and Wetzels (1999).

\section{Relationships Between Culture and Behavioral Intentions}

Perception of service quality influences behaviors and intentions. Good perceived service quality and bad perceived service quality would not lead to the same behaviors and intentions. Loyalty to company and positive word of mouth are both favorable behavioral intentions that are more likely to occur when customers are satisfied with the service quality they received. Propensity to switch, negative word of mouth, and complaining are unfavorable behavioral intentions that are more likely to occur when customers are not satisfied with the service quality they receive. Therefore, in the next paragraphs, we hypothesize two sets of relationships for the effect of the five cultural dimensions on the five behavioral intentions, one when the perception of service quality is positive and the other when the perception is negative. ${ }^{2}$

\footnotetext{
2. Furrer, Liu, and Sudharshan (2000) introduced three contingency variables to the relationships between culture and service quality perceptions: weak versus powerful customers, male versus female service provider, and a frequent versus an infrequent service situation. However, they only tested one combination of these variables (weak customers, female service provider, and frequent service situation); because we are using the same sample, we tested the same combination of the contingency variables. However, to facilitate the flow of the article, we do not present hypotheses for different combinations of the contingency variables.
} 
TABLE 2

Hypothesized Relationships Between Cultural Dimensions and Behavioral Intentions

\begin{tabular}{lccccc}
\hline & Power Distance & Individualism & Masculinity & Uncertainty Avoidance & Long-Term Orientation \\
\hline $\begin{array}{l}\text { Positive scenario } \\
\text { Loyalty to company }\end{array}$ & 0 & 0 & 0 & 0 & 0 \\
$\quad$ Positive word of mouth & - & - & + & + & + \\
Negative scenario & + & + & + & - & - \\
$\quad$ Propensity to switch & + & - & - & - & - \\
Negative word of mouth & + & + & + & - & - \\
Complaining & & & & \\
\hline
\end{tabular}

Table 2 shows the summary of our hypotheses. The reasoning for each hypothesis is provided in the following paragraphs.

\section{Positive Service Quality Scenario}

\section{LOYALTY TO THE COMPANY}

When the perceived service quality is positive, the tendency to be loyal to the company is usually high, probably through positive reinforcement, and this effect occurs independent of the culture of the customers. Therefore, we do not expect to find significant relationships between cultural dimensions and loyalty to the company when the perceived service quality is positive.

\section{POSITIVE WORD OF MOUTH}

Praising a service provider to other customers is largely influenced by culture. A study by Brown and Reingen (1987) showed a positive relationship between social ties and the use of word-of-mouth referral. Another study by Money, Gilly, and Graham (1998) showed that collectivistic and risk-adverse Japanese companies were more likely to use word-of-mouth referral in the purchase of professional services than individualistic and less riskadverse American companies. Mangold, Miller, and Brockway (1999) found that word-of-mouth communication was stimulated when two or more people were collectively trying to select a service.

On the basis of the above, we hypothesize that when the perception of service quality is positive, customers in large power distance cultures are less likely to give positive word of mouth than customers in small power distance cultures because the customers in large power distance cultures tend to be treated as having higher power and thus consider positive service quality as normal. Also, we expect that customers in individualistic cultures are less likely to give a positive word of mouth than those in collectivist cultures because of fewer channels to spread word of mouth. In masculine cultures, customers are more likely to give positive word of mouth than those in more feminine cultures because they have stronger motivation to show others the good services they received. Customers in highuncertainty avoidance cultures are more likely to praise good service quality and to give positive word of mouth than customers in low-uncertainty avoidance cultures because praising may help ease the sense of uncertainty. Finally, customers in long-term-oriented cultures are more likely to praise good service quality and to give positive word of mouth than customers in short-term-oriented cultures because praising may enhance the long-term relationship with the service provider.

\section{Negative Service Quality Scenario}

\section{Propensity to SWITCH}

When the perception of service quality is negative, customers in large power distance cultures are more likely to switch than customers in small power distance cultures because they perceive having the power to switch to another service provider. Individualists, due to their drive, selfresponsibility ethic, and demand for others to be efficient are hence more demanding than collectivists (Furrer, Liu, and Sudharshan 2000). Therefore, we hypothesize that customers in individualistic cultures are more likely to switch when they experience a problem than do customers in collectivist cultures. In masculine cultures, loyalty and harmony are less valued than in feminine cultures. People are more willing to exercise their customer power to discipline service providers by switching to others. So, in such cultures, customers are more likely to switch to other service providers than those in more feminine cultures. In cultures with high-uncertainty avoidance, switching is perceived to be associated with uncertainty, hence undesirable; therefore, in such cultures, customers are less likely to switch than customers in low-uncertainty avoidance cultures. Finally, customers in long-term-oriented cultures are more likely to stay with the same service provider to maintain a long-term relationship than customers in shortterm-oriented cultures. 


\section{Negative Word OF Mouth}

When the perception of service quality is negative, customers in large power distance cultures are more likely to spread negative word of mouth than customers in small power distance cultures because they consider themselves to have higher power and hence less tolerable with negative service quality. On the basis of Mangold, Miller, and Brockway's (1999) findings that word-of-mouth communication was stimulated when two or more people were collectively trying to select a service, we hypothesize that customers in individualistic cultures are less likely to pass on negative word-of-mouth messages than customers in collectivistic cultures because they have fewer channels to pass word of mouth. Customers in masculine cultures are less likely to engage in negative word-of-mouth messaging than customers in feminine cultures because they are unwilling to look bad in others' eyes. Finally, customers in high-uncertainty avoidance or long-term-oriented cultures are less likely to engage in negative word-ofmouth messaging than customers in low-uncertainty avoidance or short-term-oriented cultures. This is because such negative word-of-mouth messaging may have the risk of compromising long-term relationships with the service providers and thus is avoided.

\section{Complaining}

Customers' tendency to complain to the service provider is largely influenced by their cultures. Reisinger and Turner (1999) reported that Japanese, characterized by collectivistic, high-uncertainty avoidance and long-term orientation traits, regard explicit complaining or expressing dissatisfaction inappropriate and socially undesirable.

In cultures with large power distance, customers are more likely to complain when they experience a problem than customers in cultures with smaller power distance because their higher power perception enables them to express their complaining more freely. Individualists, due to their drive and self-responsibility ethic, also demand others to be efficient; therefore, they are more demanding than people in more collectivist cultures (Furrer, Liu, and Sudharshan 2000). So, in individualistic cultures, customers are more likely to complain when they experience a problem than those in collectivistic ones. In masculine cultures, customers are more likely to complain than customers in more feminine cultures because they are more willing to confront the service provider for the unsatisfactory experience. In cultures with strong-uncertainty avoidance or long-term orientation, customers are less likely to complain than in cultures with weak-uncertainty avoidance or short-term orientation. This is because a complaint could lead to confrontation, and people in such cultures are looking more at consensus and harmonious relationships (Reisinger and Turner 1999).

As mentioned in the beginning of this section, the above hypotheses are summarized in a concise format in Table 2.

\section{METHOD}

\section{Survey}

The empirical part of these studies is based on the data collected by Furrer, Liu, and Sudharshan (2000). However, the data sets for the two articles are, in essence, different. Only the cultural dimensions were common to both studies. These data were obtained from a sample of $285 \mathrm{ex}-$ ecutive or MBA students from countries with diverse cultures: 103 from the United States, 128 from Asia (China: 49, Taiwan: 24, Korea: 22, Singapore: 19, and other Asian countries [e.g., India, Indonesia, Saudi Arabia, Thailand, Turkey]: 14), 38 from the French-speaking part of Switzerland, and 16 from other countries. The participants were selected to ensure the heterogeneity of the students' cultural backgrounds. These participants all had several years of work and banking experience (some of them even worked as accounting/finance managers dealing with banks intensively). They were asked to recollect their experience with a bank in their respective personal countries of origin.

\section{Measurement}

\section{Overall Perceived \\ SERVICE QUALITY}

Because behavioral intentions are likely to change depending on the service quality, we set up two service scenarios that varied in terms of the perception of the overall quality of a bank. We asked the respondents to evaluate the likelihood of their behavior on a 7-point scale $(1=$ not likely at all, and $7=$ extremely likely) to a bank with high ratings on the five SERVQUAL dimensions (reliability, responsiveness, assurance, empathy, and tangibles; cf. Parasuraman, Zeithaml, and Berry, 1988, 1994) as well as to a bank with low ratings on the same five dimensions.

\section{BEHAVIORAL INTENTIONS}

The five behavioral intentions were measured using items similar to those used by Zeithaml, Berry, and Parasuraman (1996) and Bloemer, de Ruyter, and Wetzels (1999) and are presented in Table 3. Loyalty was measured using four positive behavioral-intention items: do more 
TABLE 3

Behavioral Intentions Operationalization

\begin{tabular}{|c|c|c|}
\hline $\begin{array}{l}\text { Behavioral } \\
\text { Intention } \\
\text { Constructs }\end{array}$ & Item Wording & $\begin{array}{l}\text { Similar to Zeithaml, } \\
\text { Berry, and Parasuraman } \\
\text { (1996) Dimensions }\end{array}$ \\
\hline \multicolumn{3}{|c|}{ Positive service quality scenario } \\
\hline \multirow[t]{4}{*}{ Loyalty to the company } & 1. Do more business with Bank $X$ in the next few years & Loyalty \\
\hline & 2. Continue to do business with Bank $\mathrm{X}$ even if its prices increase somewhat & Pay more \\
\hline & 3. Consider Bank X your first choice to buy banking services & Loyalty \\
\hline & $\begin{array}{l}\text { 4. Pay higher price than competitors charge for the benefits you currently received } \\
\text { from Bank X }\end{array}$ & Pay more \\
\hline \multirow{3}{*}{ Positive word of mouth } & 1. Encourage friends and relatives to do business with Bank X & Loyalty \\
\hline & 2. Recommend Bank X to someone who seeks your advice & Loyalty \\
\hline & 3. Say positive things about Bank X to other people & Loyalty \\
\hline \multicolumn{3}{|c|}{ Negative service quality scenario } \\
\hline \multirow[t]{2}{*}{ Propensity to switch } & 1. Take some of your business to a competitor that offers more attractive prices & Switch \\
\hline & 2. Switch to a competitor if you experience a problem with Bank X's service & External response \\
\hline \multirow[t]{3}{*}{ Negative word of mouth } & 1. Discourage friends and relatives to do business with Bank $X$ & Loyalty $(-)$ \\
\hline & 2. Not recommend Bank X to someone who seeks your advice & Loyalty (-) \\
\hline & 3. Say negative things about Bank X to other people & Loyalty (-) \\
\hline \multirow[t]{3}{*}{ Complaining } & 1. Complain to other consumers if you experience a problem with Bank X's service & External response \\
\hline & 2. Complain to Bank X's employees if you experience a problem with Bank X's service & Internal response \\
\hline & $\begin{array}{l}\text { 3. Complain to external agencies, such as the Better Business Bureau, if you experience a } \\
\text { problem with Bank X's service }\end{array}$ & External response \\
\hline
\end{tabular}

business, continue to do business with the company, consider the company first choice, and pay a higher price than competitors. Positive word of mouth was measured using three items: saying positive things about the company, recommending the company to someone who seeks advice, and encouraging friends and relatives to do business with the company. Negative word of mouth was measured using three items: discourage friends and relatives to do business with the company, not recommend the company to someone who seeks your advice, and say negative things about the company. Propensity to switch was measured using two items: take some of your business to a competitor and switch to a competitor if you experience a problem with the company's service. Finally, complaining was measured using three items: complain to other customers, complain to the company's employees, and complain to external agencies such as the Better Business Bureau.

\section{CULtuRal Dimensions}

Hofstede's cultural dimensions were originally operationalized to measure work-related values. Because the context of the study is a service situation, we used a different set of items than the one used by Hofstede (1980). We used the 20 items that Furrer, Liu, and Sudharshan (2000) developed based on items proposed by Hofstede (1991) to describe the key differences between the two poles of each dimension in terms of general norms.
These items have been selected to measure a particular cultural dimension and have been given the same weight. The indexes for each of the dimensions were computed as the average of the standardized scores for the items that comprise the dimension (the mean for each item was set to zero, and its standard deviation was set to one).

\section{RESULTS}

We analyzed the effect of culture on behavioral intentions by regressing each of the behavioral intentions on each of the cultural dimensions. We found that 76\% (19 out of 25) of the standardized regression coefficients are in the same direction as hypothesized, and 56\% (14 out of 25) of the coefficients are significant at the $10 \%$ or lower level in the same direction as hypothesized. The results are presented in Table 4. The data in Table 4 show that the effects of cultural factors on behavioral intentions are as described below.

\section{Positive Service Quality Scenario}

Loyalty to the company is operationalized by four items: (a) do more business with Bank X in the next years, (b) continue to do business with Bank $X$ even if its prices increase somewhat, (c) consider Bank X your first choice 
for banking services, and (d) pay a higher price than competitors charge for benefits you currently received from Bank X. A principal components analysis was used to compute a loyalty index. Cronbach's alpha coefficient for this index is .684. As hypothesized, no significant coefficient is found between loyalty and the five cultural dimensions.

Positive word of mouth is operationalized by three items: (a) encourage friends and relatives to do business with Bank X, (b) recommend Bank X to someone who seeks your advice, and (c) say positive things about Bank $\mathrm{X}$ to other people. A principal components analysis was used to compute a positive word-of-mouth index. Cronbach's alpha coefficient is .812. The standardized regression coefficient between positive word of mouth and power distance is significant in the negative direction $(\beta=$ -.174 at the $1 \%$ level), giving a strong support to the hypothesis. The hypothesized negative relationship between individualism and positive word of mouth is supported by a significant negative coefficient of -.130 at the $5 \%$ level. The positive relationship hypothesized between positive word of mouth and masculinity is not supported. Positive word of mouth and uncertainty avoidance are significantly positively related, giving a strong support to the hypothesis. The standardized regression coefficient is .197 at the $1 \%$ level. Finally, positive word of mouth is marginally positively influenced by long-term orientation $(\beta=.103$ at the $10 \%$ level).

\section{Negative Service Quality Scenario}

Propensity to switch is operationalized by two items: (a) take some of your business to a competitor that offers more attractive prices and (b) switch to a competitor if you experience a problem with Bank X's service. A principal components analysis was used to compute a propensity-toswitch index. Cronbach's alpha coefficient is .750. The positive relationship hypothesized between power distance and propensity to switch is not supported. The expected positive relationship between individualism and propensity to switch is supported by the significant positive coefficient ( $\beta=.146$ at the $5 \%$ level). The relationship between masculinity and propensity to switch is significant with a coefficient of -.113 at the $5 \%$ level; however, we hypothesized a positive relationship. The hypothesized negative relationship between uncertainty avoidance and propensity to switch is also supported by the significant negative coefficient ( $\beta=-.173$ at the $1 \%$ level). The negative relationship between long-term orientation and propensity to switch is not supported by the data.

Negative word of mouth is operationalized by three items: (a) discourage friends and relatives to do business with Bank X, (b) not recommend Bank X to someone who seeks your advice, and (c) say negative things about Bank $\mathrm{X}$ to other people. A principal components analysis was used to compute a negative word-of-mouth index. Cronbach's alpha coefficient is .652. The results show that the relationships between negative word of mouth and power distance and between negative word of mouth and masculinity are not supported. The relationship between individualism and negative word of mouth is marginally significant but in the opposite direction $(\beta=.104$ at the $10 \%$ level), which gives no support to the hypothesis. The hypothesized negative relationship between uncertainty avoidance and negative word of mouth is supported by a significant negative coefficient ( $\beta=-.116$ at the $5 \%$ level). Finally, the negative relationship between long-term orientation and negative word of mouth is not supported by the data.

Complaining is operationalized by three items: (a) complain to other consumers; (b) complain to Bank X's employees; and (c) complain to external agencies, such as the Better Business Bureau, if you experience a problem with Bank X's service. A principal components analysis was used to compute a complaining index. Cronbach's alpha coefficient for complaining is .559 , which is lower than the generally recommended level of .70 ; therefore, we are cautious about drawing conclusions relating to this construct. The expected relationships between complaining and four of the five cultural dimensions are not significant (power distance, individualism, masculinity, and longterm orientation). Only the negative relationship hypothesized between complaining and uncertainty avoidance is supported by the data, with a negative coefficient of -.129 at the 5\% level. The poor reliability of the complaining index may have led to the lack of significant relationships between complaining and the cultural dimensions. ${ }^{3}$

\section{INTERPRETATION OF THE RESULTS AND MANAGERIAL IMPLICATIONS}

We may summarize the above results in the following way:

1. Customers from a culture with higher power distance have lower intention to praise the service provider (given positive word of mouth) even upon experiencing positive service quality.

\footnotetext{
3. As about half of the results were not statistically significant, we might have rejected some null hypotheses by chance. Fortunately, because we used $10 \%$ as the minimum level for statistical significance, such a Type II error may potentially lead to only two null hypotheses having been rejected by chance.
} 
TABLE 4

The Empirical Relationships Between Cultural Dimensions and Behavioral Intentions $(N=285)$

\begin{tabular}{|c|c|c|c|c|c|c|c|c|c|c|}
\hline & \multicolumn{2}{|c|}{$\begin{array}{c}\text { Power } \\
\text { Distance }\end{array}$} & \multicolumn{2}{|c|}{ Individualism } & \multicolumn{2}{|c|}{ Masculinity } & \multicolumn{2}{|c|}{$\begin{array}{l}\text { Uncertainty } \\
\text { Avoidance }\end{array}$} & \multicolumn{2}{|c|}{$\begin{array}{l}\text { Long-Term } \\
\text { Orientation }\end{array}$} \\
\hline & Hypothesis & Result & Hypothesis & Result & Hypothesis & Result & Hypothesis & Result & Hypothesis & Result \\
\hline \multicolumn{11}{|l|}{ Positive scenario } \\
\hline Loyalty to the company $(\alpha=.685)$ & 0 & $n s$ & 0 & $n s$ & 0 & $n s$ & 0 & $n s$ & 0 & $n s$ \\
\hline Positive word of mouth $(\alpha=.812)$ & - & $-.174 * * *$ & - & $-.130 * *$ & + & $n s$ & + & $.197 * * *$ & + & $.103 *$ \\
\hline \multicolumn{11}{|l|}{ Negative scenario } \\
\hline Propensity to switch $(\alpha=.750)$ & + & $n s$ & + & $.146^{* *}$ & + & $-.113 * *$ & - & $-.173^{* *}$ & - & $n s$ \\
\hline Negative word of mouth $(\alpha=.652)$ & + & $n s$ & - & $.104 *$ & - & $n s$ & - & $-.116^{* *}$ & - & $n s$ \\
\hline Complaining $(\alpha=.559)$ & + & $n s$ & + & $n s$ & + & $n s$ & - & $-.129 * *$ & - & $n s$ \\
\hline
\end{tabular}

NOTE: Entries are standardized regression coefficients; $n s=$ nonsignificant.

2. Customers from a more individualistic culture have a lower intention to praise the service provider, even when they experience positive service quality, yet they exhibit a higher intention to switch to another service provider or to give negative word of mouth if they experience negative service quality.

3. Customers from a masculine culture have a lower intention to switch even when they experience negative service quality.

4. Customers from a culture with higher uncertainty avoidance have a higher intention to praise the service provider if they experience positive service quality. However, if they experience a problem, they show a lower intention to switch to another service provider, to give negative word of mouth, or to complain.

5. Customers from a culture with long-term orientation have a higher intention to praise the service provider if they experience positive service quality.

Thus, the results seem to reveal that customers from cultures with lower individualism or higher uncertainty avoidance (e.g., for a majority of individuals from Colombia, Costa Rica, El Salvador, Guatemala, Panama, Peru, South Korea, and Venezuela, according to Hofstede 1980), labeled as Type A cultures in Figure 2, tend to have a higher intention to give positive word of mouth if they received positive service quality. But they tend not to switch, give negative word of mouth, or complain even if they received poor service quality. On the contrary, customers from cultures with higher individualism or lower uncertainty avoidance (e.g., for a majority of individuals from Denmark, Great Britain, Ireland, Sweden, according to Hofstede 1980), labeled as Type B cultures in Figure 2, tend to switch, give negative word of mouth, or complain if they received poor service quality. But they do not tend to praise when they received positive service quality.

\section{FIGURE 2}

Culture Differences Toward Positive and Negative Behaviors

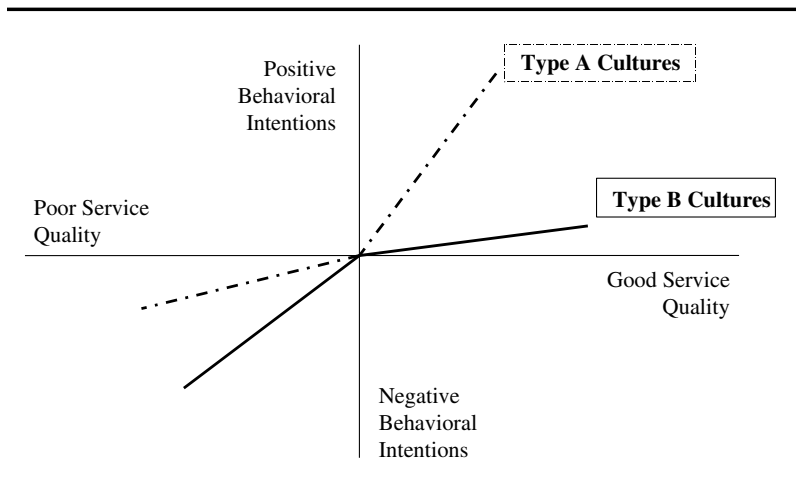

NOTE: Type A cultures: cultures with lower individualism or higher uncertainty avoidance; Type B cultures: cultures with higher individualism or lower uncertainty avoidance.

Furthermore, for service providers serving customers from Type A cultures, if customers perceived service quality to be positive, the return on positive behavioral intention for the service providers will be strong. Yet, if customers perceived service quality to be negative, the return on negative behavioral intention for the service providers will be weak. On the other hand, if the customers from Type B cultures perceived service quality to be positive, the return on positive behavioral intention for the service provider will be weak. Yet, if these customers perceived service quality to be negative, the return on negative behavioral intention will be strong. These phenomena are illustrated in Figure 3.

On the basis of the findings discussed above, we proposed the following set of managerial implications: Service providers serving customers from Type A cultures should create or even amplify their positive service quality 


\section{FIGURE 3 \\ Service Quality Strategies for Different Cultures}

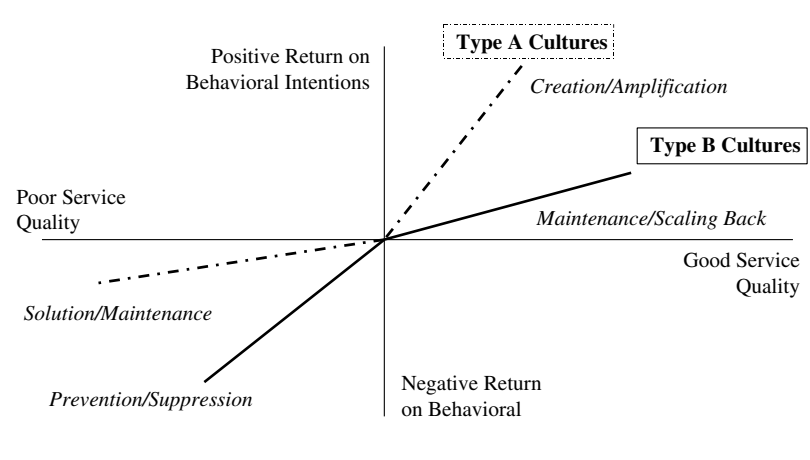

NOTE: Type A cultures: cultures with lower individualism or higher uncertainty avoidance; Type B cultures: cultures with higher individualism or lower uncertainty avoidance.

because it will gain a lot of positive behavioral intention in return. We call this the creation/amplification strategy. However, when service quality is perceived to be poor by customers from Type A cultures, the improvement of this quality may be too costly compared to the return that can be expected from such an action. So, service providers may adjust only slightly or even maintain the similar level of service quality. We call this the solution/maintenance strategy. On the other hand, when serving customers from Type B cultures, service providers should avoid being perceived negatively because the loss to negative behavioral intention is potentially huge. If a negative perception does occur, service providers should make the necessary effort to rapidly suppress the negative quality impression. We call this the prevention/suppression strategy. In such a situation, the return on service quality investment is expected to be large. However, when service quality is perceived to be positive by customers from Type B cultures, service providers may maintain or even scale back the level of service quality because any change in service quality will have only a weak effect on customers' behavioral intentions. We call this the maintenance/scaling-back strategy. These different strategies are described in Table 5.

\section{CONCLUSION}

On the basis of the results discussed above, we conclude that cultural factors do influence behavioral intentions as hypothesized. In particular, customers from cultures with lower individualism or higher uncertainty avoidance tend to have a higher intention to praise if they receive positive service quality. But they tend not to complain even if they receive poor service quality. On the contrary, customers from cultures with higher individualism or lower uncertainty avoidance tend to complain if they receive poor service quality. But they do not tend to praise when they receive positive service quality.

The pattern of variation across cultures in intentions to give positive feedback or to complain leads us to recommend four types of service quality strategies, each corresponding to a different marketing situation. Applying an appropriate or nonappropriate strategy to the market situation a manager faces can lead to gain or loss of a huge amount of resources. Therefore, using the proposed strategies can help managers to make more effective and efficient decisions on resources allocation.

With the increase of intercultural service encounters (i.e., service providers and customers are from different cultures, for example, Japanese tourists encounter American airlines and European hotel/restaurant services), service providers' expected return on service quality may be quite different from customers' perceived experience, hence the behavioral intentions. Therefore, carefully studying the potential cultural influence on customers' behavioral intentions and adjusting the service decisions can help avoid possible managerial cultural bias and increase business profitability.

Our findings also render support to Triandis's (1980) proposal that culture may influence the relationship between attitudinal variables and behavior by making certain norms and expectations more plausible than others. Specifically, our findings seem to show that self-instructions (intentions) may be determined by sociocultural norms. Thus, the utility of a behavior in the social domain may be a fundamental component of the decision to perform it.

Based on a framework such as that of Triandis, our findings may be interpreted as follows: Cultural factors may have influenced customers' behavioral intentions through changing perceived service quality as well as moderated the effect of perceived service quality on behavioral intentions by providing an overarching frame in the formation of behavioral intentions. Therefore, we propose that future research should be directed toward empirically testing the indirect and moderating effects of cultural factors on behavioral intentions, respectively. Doing so would contribute to the theoretical development in the literature of cross-cultural service marketing and provide a guideline to design an effective service marketing program in an international market arena.

The small yet significant standardized regression coefficients found in our empirical results imply that although there are many other factors (such as personality and situa- 
TABLE 5

Cross-Cultural Service Quality Strategies

\begin{tabular}{|c|c|c|}
\hline & Type A Cultures ${ }^{\mathrm{a}}$ & Type B Cultures ${ }^{\mathrm{b}}$ \\
\hline Good service quality & $\begin{array}{l}\text { Creation/amplification strategy } \\
\text { Create or even amplify positive service } \\
\text { quality because it will gain a lot of positive } \\
\text { behavioral intention in return }\end{array}$ & $\begin{array}{l}\text { Maintenance/scaling-back strategy } \\
\text { Maintain or even scale back the level of service quality if that will result } \\
\text { in significant cost-efficiency because the return on positive behavioral } \\
\text { intention under this situation is weak }\end{array}$ \\
\hline Poor service quality & $\begin{array}{l}\text { Solution/maintenance strategy } \\
\text { If the cost to improve service quality is } \\
\text { high, the service providers may adjust } \\
\text { only slightly or even maintain the similar } \\
\text { level of service quality for the return on } \\
\text { negative behavioral intention is weak }\end{array}$ & $\begin{array}{l}\text { Prevention/suppression strategy } \\
\text { Avoid being perceived negatively since the loss to negative behavioral } \\
\text { intention is huge } \\
\text { If a negative perception does occur, service providers should make the } \\
\text { necessary effort to suppress the negative quality impression }\end{array}$ \\
\hline
\end{tabular}

a. Low individualism, high uncertainty avoidance (e.g., Colombia, Costa Rica, El Salvador, Guatemala, Panama, Peru, South Korea, and Venezuela). b. High individualism, low uncertainty avoidance (e.g., Denmark, Great Britain, Ireland, and Sweden).

tional factors) influencing behavioral intentions, culture factors cannot be overlooked.

Finally, because culture is constantly evolving, studying the evolution of cultures over time and its impact on behavioral intentions may produce fruitful results as well.

\section{REFERENCES}

Anderson, Eugene W. and Mary Sullivan (1993), "The Antecedents and Consequences of Customer Satisfaction for Firms," Marketing Science, 12 (2), 125-43.

Argyle, M., M. Henderson, M. Bond, Y. Iizuka, and A. Contarello (1986), "Cross-Cultural Variations in Relationship Rules," International Journal of Psychology, 21, 287-315.

Berry, John W., Ype H. Poorting, M. H. Segall, and P. R. Dasen (1992), Cross-Cultural Psychology: Research and Applications. Cambridge, UK: Cambridge University Press.

Bianchi, Constanza C. (2001), "The Effect of Cultural Differences on Service Encounter Satisfaction," in Marketing Theory and Applications, Vol. 12, 2001 American Marketing Association Winter Educators' Conference, R. Krishnan and M. Viswanathan, eds. Chicago: American Marketing Association, 46-52.

Bloemer, Josée, Ko de Ruyter, and Martin Wetzels (1999), "Linking Perceived Service Quality and Service Loyalty: A Multi-Dimensional Perspective," European Journal of Marketing, 33 (11/12), 10821106.

Bond, Michael H. et al. (1987), "Chinese Values and the Search for Culture-Free Dimensions of Culture," Journal of Cross-Cultural Psychology, 18 (2), 143-64.

Boulding, William, Ajay Kalra, Richard Staelin, and Valarie A. Zeithaml (1993), “A Dynamic Process Model of Service Quality: From Expectations to Behavioral Intentions," Journal of Marketing Research, 30 (1), 7-27.

Brown, Jaqueline Johnson and Peter H. Reingen (1987), "Social Ties and Word-of-Mouth Referral Behavior," Journal of Consumer Research, 14 (3), 350-62.

Brown, S. (1997), "Service Recovery Through Information Technology: Complaint Handling Will Differentiate Firms in the Future," Marketing Management, 6 (3), 25-27.

Cronin, J. Joseph, Jr. and Steven A. Taylor (1992), "Measuring Service Quality: A Reexamination and Extension," Journal of Marketing, 56 (2), 55-68.
Donthu, Naveen and Boonghee Yoo (1998), "Cultural Influences on Service Quality Expectations," Journal of Service Research, 1 (2), 178-86.

Furrer, Olivier, Ben Shaw-Chimg Liu, and D. Sudharshan (2000), "The Relationships between Culture and Service Quality Perceptions: Basis for Cross-Cultural Market Segmentation and Resource Allocation," Journal of Service Research, 2 (4), 355-71.

Hofstede, Geert (1980), Culture's Consequences: International Differences in Work-Related Values. Beverly Hills, CA: Sage.

(1991), Cultures and Organizations: Software of the Mind. London: McGraw-Hill.

Liu, Ben S., D. Sudharshan, and Lawrence O. Hamer (2000), "AfterService Response in Service Quality Assessment: A Real-Time Updating Model Approach," Journal of Service Marketing, 14 (2), 160-77.

Malhotra, N., F. Ugaldo, J. Agarwal, and I. Baalbaki (1994), "International Service Marketing: A Comparative Evaluation of the Dimensions of Service Quality in Developed and Developing Countries," International Marketing Review, 11 (2), 5-15.

Mangold, W. Glynn, Fred Miller, and Gary R. Brockway (1999), "Wordof-Mouth Communication in the Service Marketplace," Journal of Service Marketing, 13 (1), 73-90.

Mattila, Anna S. (1999), "The Role of Culture in the Service Evaluation Processes," Journal of Service Research, 1 (3), 250-61.

Money, R. Bruce, Mary C. Gilly, and John L. Graham (1998), "Explorations of National Culture and Word-of-Mouth Referral Behavior in the Purchase of Industrial Services in the United States and Japan," Journal of Marketing, 62 (4), 76-87.

Nakata, Cheryl and K. Sivakumar (1996), "National Culture and New Product Development: An Integrative Review," Journal of Marketing, 60 (1), 61-72.

Parasuraman, A., Valarie A. Zeithaml, and Leonard L. Berry (1988), "SERVQUAL: A Multiple-Item Scale for Measuring Consumer Perceptions of Service Quality,” Journal of Retailing, 64 (1), 12-40.

— — - and (1994), "Alternative Scales for Measuring Service Quality: A Comparative Assessment Based on Psychometric and Diagnostic Criteria," Journal of Retailing, 70 (3), 201-30.

Poortinga, Ype H. (1990), "Towards a Conceptualization of Culture for Psychology," Cross-Cultural Psychology Bulletin, 24 (3), 2-10.

Reichheld, Frederick F. (1996), The Loyalty Effect. Boston, MA: Harvard Business School Press.

— and W. Earl Sasser Jr. (1990), "Zero Defections: Quality Comes to Services," Harvard Business Review, 68 (5), 105-11.

- and Phil Schefter (2000), "E-Loyalty," Harvard Business Review, 78 (4), 105-113. 
Reisinger, Yvette and Lindsay Turner (1999), "A Cultural Analysis of Japanese Tourists: Challenges for Tourism Marketers," European Journal of Marketing, 33 (11/12), 1203-27.

Shweder, R. A. (1990), "Cultural Psychology: What Is It?" in Cultural Psychology: Essays on Comparative Human Development, J. W. Stigler, R. A. Shweder, and G. Herdt, eds. Cambridge, UK: Cambridge University Press, 1-43.

Sivakumar, K. and Cheryl Nakata (1999), "The Stampede Toward Hofstede's Framework: Avoiding the Sample Design Pit in CrossCultural Business Studies," AMA Summer Educators' Conference, San Francisco.

Sødergaard, Mikael (1994), "Hofstede's Consequences: A Study of Reviews, Citations and Replications," Organization Studies, 15 (3), 447-56.

Strauss, B. and P. Mang (1999), “'Culture Shocks' in Inter-Cultural Service Encounters?" Journal of Service Marketing, 13 (3/4), 329-46.

Sultan, Fareena and Merlin C. Simpson Jr. (2000), "International Service Variants: Airline Passenger Expectations and Perception of Service Quality," Journal of Services Marketing, 14 (3), 188-216.

Tax, S., S. Brown, and M. Chandrashekaren (1996), "Customer Evaluations of Service Complaint Experiences: Implications for Relationship Marketing," working paper, Center for Service Marketing \& Management, College of Business, Arizona State University, Tempe.

Triandis, Harry C. (1980), "Values, Attitudes, and Interpersonal Behavior," in Nebraska Symposium on Motivation, 1979, H. E. Howe and M. M. Page, eds. Lincoln: University of Nebraska Press, 195-260.

(1994), Culture and Social Behavior. New York: McGraw-Hill.

Winsted, Kathryn Frazier (1997), "The Service Experience in Two Cultures: A Behavioral Perspective," Journal of Retailing, 73 (3), 337-60.

(1999), "Evaluating Service Encounters: A Cross-Cultural and Cross-Industry Exploration," Journal of Marketing Theory and Practice, 7 (2), 106-23.

Woodside, A., L. Frey, and R. Daly (1989), "Linking Service Quality, Customer Satisfaction and Behavioral Intention," Journal of Health Care Marketing, 9 (December), 5-17.

Zeithaml, Valarie A., Leonard L. Berry, and A. Parasuraman (1996), "The Behavioral Consequences of Service Quality," Journal of Marketing, 60 (2), 31-46.

Ben Shaw-Ching Liu is an associate professor of marketing at Butler University, Indianapolis. He was an assistant professor of marketing at the University of Illinois at Urbana-Champaign between 1991 and 1999. He holds a Ph.D. from the State University of New York at Buffalo. His major research interest is in the areas of service marketing, negotiation behaviors of buyers and sellers, distribution channel member relationships, and positioning strategy in new product development. He has published various articles in the Journal of Service Research, the Journal of Service Marketing, the Journal of Foodservice Systems, the Journal of Product and Brand Management, the Journal of Marketing Theory and Practice, and Industrial Marketing Management.

Olivier Furrer is a lecturer in marketing at the Birmingham Business School in the United Kingdom. He will become an associate professor of strategic management at the Nijmegen Business School in the Netherlands in September 2001. He holds a $\mathrm{Ph}$.D. from the University of Neuchâtel (Switzerland). His major research interests are in the areas of service marketing, customer services, resource-based theory, and the strategic role of intangible assets. He is the author of a book recently published in French about the strategic role of customer services: Services autour des Produits: Enjeux et Stratégies. He has published in journals such as the Journal of Service Research, the European Management Journal, Revue Française de Gestion, and Revue Française du Marketing.

D. Sudharshan is a professor of business administration in the College of Commerce and Business Administration at the University of Illinois. His research is in the areas of marketing strategy, new product and service development, and marketing technology management. He serves on the editorial boards of the Journal of Marketing and the Journal of the Academy of Marketing Science. His articles have appeared in various journals, including Marketing Science, the Journal of Marketing, the Journal of Marketing Research, the Strategic Management Journal, the European Journal of Operation Research, the Journal of Service Research, and the Journal of Market Focused Management. 